\title{
Responses of riffle beetle assemblages to deforestation in a semi-deciduous Atlantic Forest remnant
}

\author{
BRUNA M. BRAUN ${ }^{1}$, TIAGO R.N. BERTASO ${ }^{1}$, MATEUS M. PIRES ${ }^{2}$, \\ MARCIA R. SPIES ${ }^{3}$ and CARLA B. KOTZIAN ${ }^{1}$ \\ ${ }^{1}$ Programa de Pós-Graduação em Biodiversidade Animal, Centro de Ciências Naturais e Exatas, \\ Universidade Federal de Santa Maria, Avenida Roraima, 1000, 97105-900 Santa Maria, RS, Brazil \\ ${ }^{2}$ Programa de Pós-Graduação em Biologia, Escola Politécnica, Universidade do Vale do \\ Rio dos Sinos, Avenida Unisinos, 950, 93022-750 São Leopoldo, RS, Brazil \\ ${ }^{3}$ Universidade Federal do Pampa, Avenida Antônio Trilha, 1847, 97300-000 São Gabriel, RS, Brazil
}

Manuscript received on December 9, 2016; accepted for publication on October 9, 2017

\begin{abstract}
Deforestation affects freshwater assemblages since aquatic organisms are dependent on the structure of the riparian vegetation. To investigate the responses of riffle beetles (Elmidae) to deforestation, this study assessed the structure of riffle beetle assemblages found in streams running through a large and wellpreserved semi-deciduous Atlantic Forest remnant in Southern Brazil and in nearby deforested areas. Additionally, the effects of different substrate types (litter and stone) on the assemblages were assessed. Riffle beetle assemblages showed a remarkably distinct structure between forested and deforested areas. Lower abundance occurred in deforested streams. Indicator genera of forested streams were detected (e.g., Macrelmis and Microcylloepus), while a generalist genus (Heterelmis) predominated in deforested streams. Substrate type did not affect the composition of riffle beetle genera, although higher abundance was found in litter. Our results are likely associated with changes in the vegetation type and levels and quality of allochthonous material input between forested (native and higher levels) and deforested (exotic and lower levels) streams, which are directly linked to the feeding habits of riffle beetles. Thus, our study reveals an interesting potential of riffle beetles as indicators of stream ecological integrity in semi-deciduous areas of the Atlantic Forest biome.
\end{abstract}

Key words: Coleoptera, converted areas, elmidae, forest integrity, riparian vegetation.

\section{INTRODUCTION}

Forest ecological integrity plays an important role in the conservation of the stream fauna (Nessimian et al. 2008). Shading provided by riparian vegetation

Correspondence to: Bruna Marmitt Braun

E-mail: brumbraun@gmail.com

* Contribution to the centenary of the Brazilian Academy of Sciences. regulates water temperature, dissolved oxygen concentration and primary production in streams (Lorion and Kennedy 2009). Riparian vegetation acts as a buffer against the effects of terrestrial human activities, as it reduces bank erosion, siltation and flooding through the filtering of undesirable particles entering the water (Roy et al. 2003, Reid et al. 2010). In addition, the aquatic food 
web structure is influenced by riparian vegetation through the input of allochthonous organic matter (Weigel et al. 2003, Frady et al. 2007, Lorion and Kennedy 2009). Therefore, deforestation leads to changes in the water quality and trophic structure of streams, impacting its associated fauna such as macroinvertebrates (Lorion and Kennedy 2009, Reid et al. 2010, Iñiguez-Armijos et al. 2014, Márquez et al. 2015).

Many studies have assessed the responses of stream macroinvertebrates to alterations in riparian vegetation such as deforestation and land use conversion. Alterations in riparian vegetation can directly influence macroinvertebrates, because they are dependent on the quality of organic matter entering the streams for their feeding habits (Márquez et al. 2015, Graça et al. 2015). Responses to such environmental alterations include changes in macroinvertebrate assemblage structure (composition and richness) (Lorion and Kennedy 2009, Corbi et al. 2013). Additionally, changes in specific riparian vegetation features can also affect macroinvertebrate assemblage structure. Such features include riparian vegetation size, width (buffer effect), longitudinal position (upstream, downstream), composition (tropical, temperate deciduous) and distance from other forest fragments and converted areas (Roy et al. 2003, Fend and Carter 2005, Death and Collier 2010, Reid et al. 2010, Nessimian et al. 2008, Lorion and Kennedy 2009, Corbi et al. 2013, IñiguezArmijos et al. 2014). However, macroinvertebrate assemblage responses are not standardized (Fend and Carter 2005) since other environmental factors may interact with riparian vegetation features (e.g. regional geomorphology and superficial geology), and hinder the finding of clearer patterns (Shearer and Young 2011).

Riffle beetles (Elmidae) are coleopterans that inhabit lotic systems with well-oxygenated waters with strong currents during the larval and adult stages (Brown 1987, Passos et al. 2003a, b, Couceiro et al. 2007, Elliott 2008, Braun et al. 2014a) and commonly found in well-preserved streams (Braun et al. 2014b). Some genera have been associated with streams running through well-preserved and sometimes large forested areas (Weigel et al. 2003, Iñiguez-Armijo et al. 2014), while others seem to be tolerant to forest conversion and can be abundant in deforested streams (Paula and Fonseca-Gessner 2010). Thus, the structure of riffle beetle assemblages could constitute an important environmental indicator of forest ecological integrity. The limited dispersal ability of adult and larval stages of riffle beetles (Elliott 2008) reinforces their potential role as environmental indicators because they should be sensitive to alterations in local environmental conditions.

The presence of leaves, macrophytes, and woody debris in the stream substrate is also an important driver of riffle beetle assemblages (Passos et al. 2003a, b, Braun et al. 2014a), which suggests a direct relationship between riffle beetles and the quality of the vegetal remains arriving into streams. The relationship of riffle beetles with organic matter is related to their scraper or shredder feeding habits (White and Brigham 1996). However, subtropical streams with stony streambeds can also sustain rich and abundant riffle beetle assemblages (Braun et al. 2014a). Adult and larval riffle beetles feed on periphyton or scrape organic matter from rocks, roots, leaves and wood (Brown 1972, Seagle Jr 1982). In fact, riffle beetle feeding habits can also differ according to the life stage in some genera (Tomanova et al. 2006).

This study assessed the responses of riffle beetle assemblages to deforestation in a well-preserved subtropical semi-deciduous Atlantic Forest remnant. Considering that the riparian vegetation influences the occurrence and composition of riffle beetles (Weigel et al. 2003, Paula and FonsecaGessner 2010, Iñiguez-Armijo et al. 2014), we hypothesized that riffle beetle assemblage structure 
will change between forested and deforested streams, because riffle beetles are sensitive to changes in structure of riparian vegetation such as land use (natural vs. converted) and composition (native vs. exotic), mostly through changes in the quality of the vegetal remains. In addition, due to the low richness of riffle beetle genera recorded in southern Brazilian streams (Braun et al. 2014a, b), we expected to find (i) higher abundance in forested streams (rather than richness) and (ii) more tolerant genera to predominate in deforested streams. The effects of litter and stone substrates on riffle beetles were also assessed, as substrate type is an important driver of riffle beetle assemblage structure (Passos et al. 2003b, Braun et al. 2018). Considering that riffle beetles have different feeding habits, we expected to find changes in the composition of riffle beetles between substrates, because they provide different feeding sources to stream insects. In addition, we investigated whether riffle beetle genera were indicative of forested and deforested streams, though previous studies that indicate plasticity in the feeding habits of some riffle beetle genera (Tomanova et al. 2006) prevented us from previous expectations.

\section{MATERIALS AND METHODS}

\section{STUDY AREA}

The study was conducted in the Parque Estadual do Turvo (PET) conservation unit and nearby areas, located on the Southern Plateau (Planalto Meridional, Rio Grande do Sul State; 27¹4'34.08”S, 5357'13.74”'W; ca. 400 m a.s.l.; Fig. 1) (SEMA 2005). The PET is the largest environmentally protected area in Southern Brazil (17,491-ha area, 90-km-long perimeter). It comprises a significant portion of the preserved semi-deciduous Atlantic Forest in the region (Oliveira-Filho et al. 2015) and extends over 65,000 ha in Argentina (Iguazú National Park) (Martínez et al. 2009).
The land use near the conservation unit is characterized by soybean culture and pasture (SEMA 2005), and streams commonly have riparian vegetation. The northern boundary of the study area is delimited by the Uruguay River basin, into which the streams running through the PET and adjacent agriculture areas drain (Fig. 1). The climate in the region is subtropical and sub-humid with a dry summer (Maluf 2000), and the mean annual rainfall is $\sim 1,665 \mathrm{~mm}$, well distributed throughout the year (SEMA 2005). In general, the streams run through a geomorphologically dissected region composed of deep valleys carved on the basalt rocks of the Serra Geral Formation (SEMA 2005).

\section{SAMPLING}

Samplings were conducted during austral summer (between 23 and 25 January 2011) in six small-order streams $\left(1^{\text {st }}\right.$ and $2^{\text {nd }}$ order, according to Strahler's classification) during a period of low precipitation. These climatic conditions are favorable for collecting riffle beetles in southern Brazilian streams (Braun et al. 2014a). Three streams (F1, F2, and F3) were located within the PET (forested streams), and the other three $(\mathrm{C} 1, \mathrm{C} 2$, and $\mathrm{C} 3)$ were located outside the PET (deforested streams) in a deforested area that had been converted to agricultural land use near the edge of the PET (Fig. 1). In both areas, the streams had riparian vegetation and were similarly shadowed, but in the deforested areas, vegetation included exotic species such as Eucalyptus and Japanese raisin tree (Hovenia dulcis) (Bertaso et al. 2015).

Riffle beetles were collected using a Surber sampler $\left(0.0361-\mathrm{m}^{2}\right.$ area, 250- $\mu \mathrm{m}$ mesh size). Samplings were performed within a $\sim 50 \mathrm{~m}$ reach in each stream. Ten subsamples were collected in each reach (five in litter substrate and five in stone substrate), which were posteriorly pooled according to substrate type. Sampling reaches had no wood or aquatic plants in order to assess the 


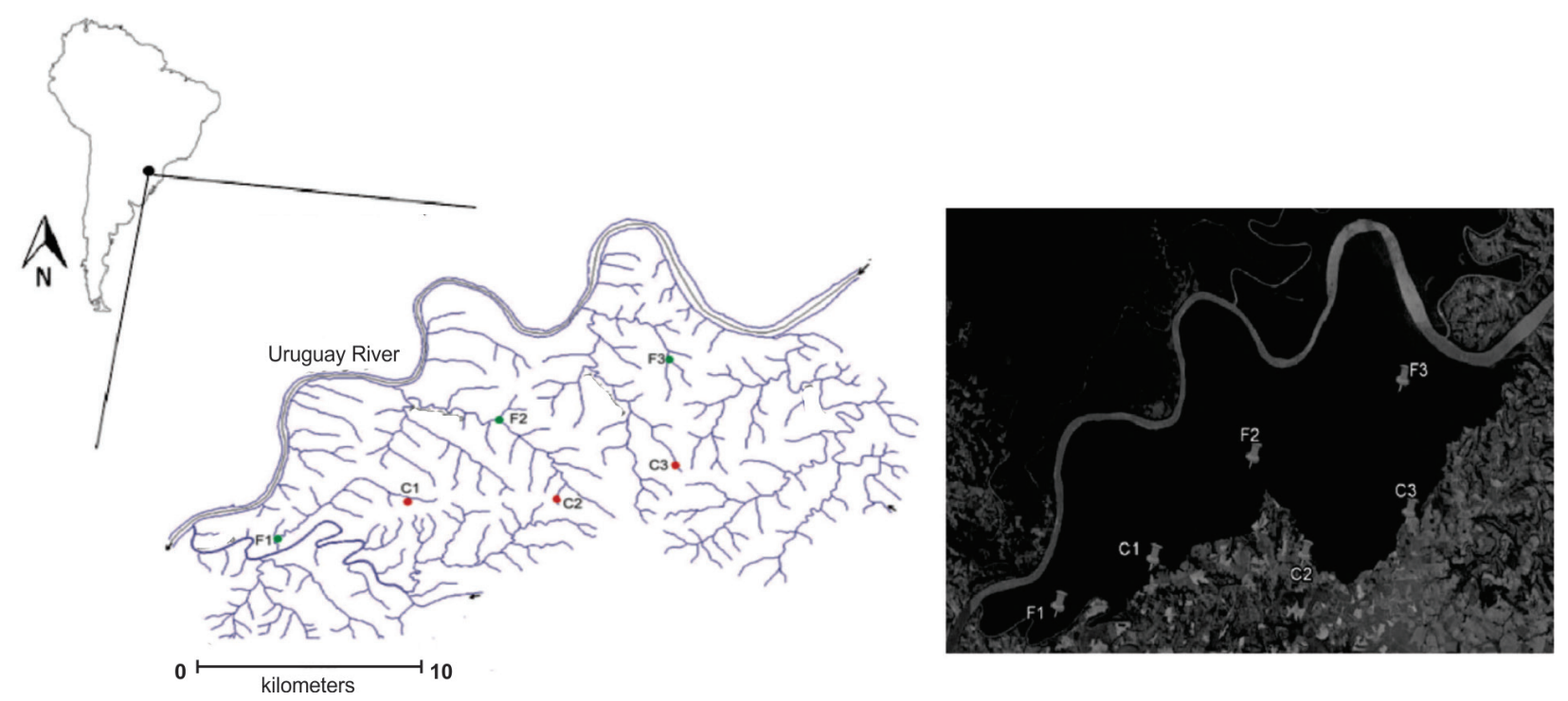

Figure 1 - Location of the sampled streams in forested (F1, F2, and F3) and converted areas (C1, C2, and C3) at Parque Estadual do Turvo and adjacent areas, in Southern Brazil. Adapted from: Bertaso et al. 2015.

effect of litter and stone substrate on riffle beetle assemblage structure. Riffle beetles were identified at genus level since the diversity of Neotropical Elmidae in southern Brazil is poorly known at species level (Domínguez and Fernández 2009). Furthermore, many specimens occurred as larvae, which are identifiable at only genus level by the available taxonomic keys (Manzo 2005, Passos et al. 2007, Segura et al. 2012, Barbosa et al. 2013). Specimens were deposited in the Collection of Aquatic Insects at Federal University of Pampa (UNIPAMPA).

Some landscape-scale environmental descriptors were obtained for each sampling site, such as the distance from the forest edge ('BorDist'; $\mathrm{m})$ and riparian vegetation features. The latter include the length of riparian vegetation upstream ('RipVegL'; m); percentages of native vegetation cover ('NatVeg') and converted area ('Land use'), both of which were measured within an arbitrarily defined buffer of $\sim 100 \mathrm{~m}$ around each sampling site in deforested areas; and riparian vegetation width ('RipVegW'; m), which was measured considering the sum of both bank widths. Measures of RipVegW were standardized to $500 \mathrm{~m}$ in forested streams to avoid overestimation in data analysis. These measures were taken from Google Earth images (dated from February 2011), and followed similar methodology used in previous studies conducted in subtropical streams (Moraes et al. 2014, Salvarrey et al. 2014).

The following local-scale environmental descriptors were taken at each sampling site: percentage of siltation (visually estimated), stream width, and stream depth $(\mathrm{cm})$. In addition, water abiotic descriptors such as water temperature (WT; $\left.{ }^{\circ} \mathrm{C}\right)$, electric conductivity $(\mathrm{EC} ; \mu \mathrm{S} / \mathrm{cm})$, dissolved oxygen (DO; mg/L), and turbidity (Turb; NTU) were measured with a multiparameter probe.

\section{DATA ANALYSIS}

Riffle beetle assemblage structure was previously assessed through non-metric multidimensional scaling (NMDS) ordination diagrams. Differences in riffle beetle assemblage structure between forested and deforested streams were tested 

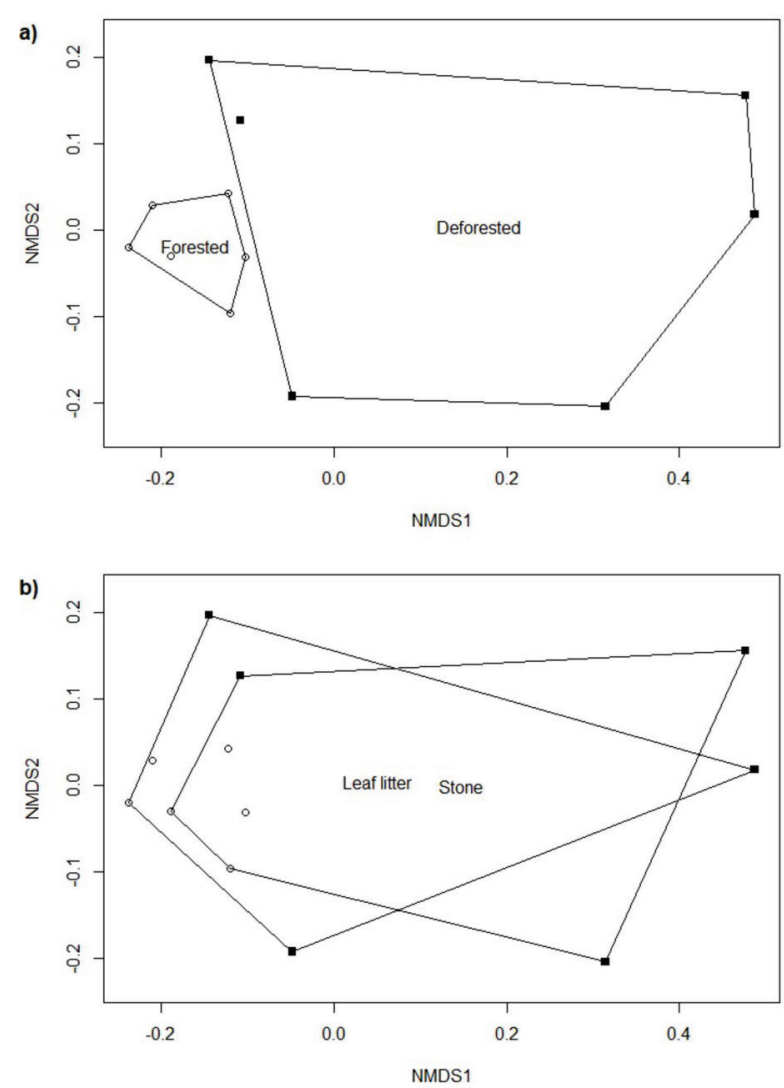

Figure 2 - Non-metric multidimensional scaling (NMDS) ordination diagram of samples from a) forested (white squares) and deforested (filled squares) areas; b) substrate types.

through a non-parametric MANOVA followed by 9,999 permutations (perMANOVA). In this analysis, the larval and adult stages of each genus were pooled (i.e., eight entries), because their feeding habits might not be strongly affected by differences in riparian vegetation quality. The influence of substrate type (litter vs. stone) on riffle beetle assemblage structure was also tested through a perMANOVA. The fauna matrix used in this analysis, however, kept the larval and adult stages separate (i.e., fourteen entries) in order to assess whether life stages respond differently to the substrate type according to previous studies (Tomanova et al. 2006). The NMDS and perMANOVA analyses were conducted with distance matrices (Bray-Curtis dissimilarity index) based on a log transformed matrix of the fauna.
Both analyses were performed using the $\mathrm{R}$ vegan package.

Redundancy analysis (RDA) was used to assess the influence of environmental descriptors on the spatial distribution of riffle beetle genera and their life stages in the study area. Since percentages of land use, native vegetation cover and siltation were highly correlated, the model included only the distance from the forest edge, land use and stream width. This method was also efficient in removing the multicollinearity among the explanatory variables, since none of them showed a high inflation factor (VIF) (sensu ter Braak and Šmilauer 2002). A Monte Carlo test (999 randomizations) was used to test the significance of the canonical axes (ter Braak and Šmilauer 2002). The biotic data were Hellinger transformed. The environmental percentage descriptors were arcsine transformed, and the others were square-root transformed and standardized by standard deviation. RDA was performed using the statistical software CANOCO v. 5.0 .

An indicator species analysis (ISA) based on the indicator value (Indval; (Dufrêne and Legendre 1997)) was performed to highlight the relationships between Elmidae genera and their life stages with forest integrity and substrate type. Indval considers the taxa fidelity and relative abundance in groups established a priori to identify the indicator taxa of each group (Dufrêne and Legendre 1997). Significance values (p) were obtained after 1,000 randomizations, and the analysis was performed using the R labdsv package.

\section{RESULTS}

Similar values of water abiotic descriptors were found in forested and deforested streams. In turn, higher values of landscape-scale environmental predictors (BorDist, NatVeg, RipVegW, and RipVegL and land use) were found in forested 
streams, as expected. Siltation values were higher in deforested streams (Table I).

We collected 1,400 individuals from eight genera and one unidentified taxon (Table II). Adult and larval stages of five genera were found. Hexanchorus Sharp, 1882 was found only as larvae, and Cylloepus Erichson, 1847 and Phanocerus Sharp, 1882, only as adults. Higher abundance of riffle beetles was found in forested streams (895) and litter substrate (956). The larval stage of Heterelmis Sharp, 1882 was dominant in both forested and deforested streams and in litter substrate, and its adult stage was predominant in deforested streams and in both substrate types.

The NMDS ordination diagram showed a clear segregation between forested and deforested streams (Fig. 2a; stress $=0.07$ ), but not between substrate types (Fig. 2b; stress $=0.06$ ). Riffle beetle assemblage structure differed significantly between forested and deforested streams ( $p$ seudo- $\mathrm{F}_{1,11}=4.72$; $\mathrm{R}_{2}=0.32 ; \mathrm{p}=0.003$ ), but not between substrate types ( $p$ seudo- $\mathrm{F}_{1,11}=0.88 ; \mathrm{p}=0.3$ ). The RDA axes were significantly different from chance $(F=$ $2.047, \mathrm{p}=0.047)$. The first two axes summarized $67.1 \%$ of the variance in riffle beetle abundance data and explained $88.9 \%$ of their relationship with the environmental descriptors (Table III). The first RDA axis showed a strong positive correlation with the distance from the forest edge (0.7533) and a strong negative correlation with land use (0.9403) and stream width (0.8914) (Fig. 3). The second RDA axis showed a strong negative correlation with the distance from the forest edge (0.6103) (Fig. 3). In general, the first RDA axis segregated forested from deforested streams (Fig.3).

Some riffle beetle genera were influenced by the environmental gradient reflecting deforestation (Fig. 3). Adult and larval stages of Neoelmis Musgrave, 1935 and larvae of Macrelmis Motschulsky, 1859 showed close relationships with forested streams. There were no strong relationships with the distance from forest edge for both life stages of

TABLE I

Values of environmental descriptors recorded at sampled streams in forested (F) and deforested (C) areas. Numbers 1-3 refer to each sampled stream. For abbreviation of environmental variables, see Materials and Methods section.

\begin{tabular}{|c|c|c|c|c|c|c|}
\hline \multirow[b]{2}{*}{ Variables } & \multicolumn{3}{|c|}{ Forested streams } & \multicolumn{3}{|c|}{ Deforested streams } \\
\hline & F1 & F2 & F3 & $\mathrm{C} 1$ & $\mathrm{C} 2$ & $\mathrm{C3}$ \\
\hline \multirow{2}{*}{ Coordinates } & $27^{\circ} 16^{\prime} 13.3 ” S$ & $27^{\circ} 12^{\prime} 56.4^{\prime \prime} \mathrm{S}$ & $27^{\circ} 11^{\prime} 15.8 ’ \mathrm{~S}$ & $27^{\circ} 15,11.03 ” S$ & $27^{\circ} 15^{\prime} 07.1$ 's & $27^{\circ} 14^{\prime} 11.2 ” \mathrm{~S}$ \\
\hline & $54^{\circ} 01^{\prime} 04.2^{\prime \prime} \mathrm{W}$ & $53^{\circ} 55^{\prime} 34.7^{\prime \prime} \mathrm{W}$ & $53^{\circ} 51^{\prime} 22.4^{\prime \prime} \mathrm{W}$ & $53^{\circ} 57^{\prime} 50.01^{\prime \prime} \mathrm{W}$ & $53^{\circ} 54^{\prime} 09.46^{\prime \prime} \mathrm{W}$ & $53^{\circ} 51^{\prime} 13.55^{\prime \prime} \mathrm{W}$ \\
\hline WT $\left({ }^{\circ} \mathrm{C}\right)$ & 26.15 & 23.36 & 23.04 & 25.3 & 22.27 & 24.74 \\
\hline DO (mg/L) & 8.42 & 9.13 & 9.34 & 9.14 & 10.39 & 9.41 \\
\hline $\mathrm{EC}(\boldsymbol{\mu S} / \mathrm{cm})$ & 50 & 91 & 79 & 45 & 53 & 58 \\
\hline Turb (NTU) & 3.27 & 2.4 & 2.9 & 2.6 & 1.2 & 0.6 \\
\hline Width (m) & 0.6 & 1.48 & 1.17 & 0.6 & 1.91 & 1.62 \\
\hline Depth (cm) & 4.5 & 4.5 & 6.3 & 4.9 & 4.9 & 6.6 \\
\hline $\begin{array}{c}\text { RipVegW } \\
\text { (m) }\end{array}$ & 500 & 500 & 500 & 40 & 70 & 10 \\
\hline RipVegL (m) & 1.000 & 1.300 & 1.500 & 200 & 140 & 40 \\
\hline $\begin{array}{c}\text { Land use } \\
(\%)\end{array}$ & 0 & 0 & 0 & 70 & 60 & 90 \\
\hline NatVeg (\%) & 100 & 100 & 100 & 60 & 85 & 20 \\
\hline Siltation (\%) & 0 & 0 & 0 & 10 & 7 & 20 \\
\hline BorDist (m) & 600 & 1.100 & 2.850 & -220 & -1.000 & -100 \\
\hline
\end{tabular}




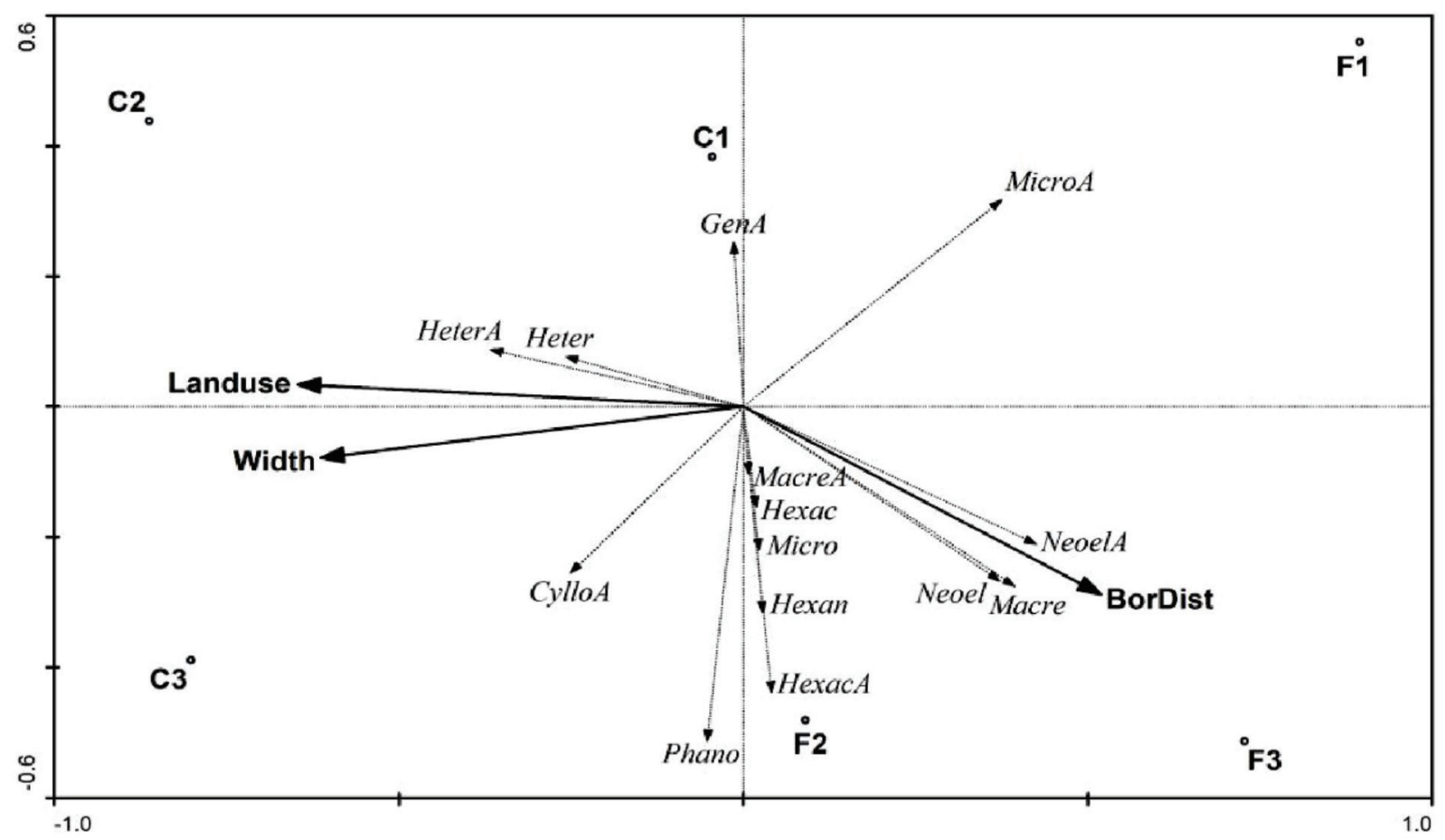

Figure 3 - Ordination diagram of streams and riffle beetle genera assemblages of the Redundancy Analysis constrained by land use, distance from the forest edge, and stream width in Parque Estadual do Turvo. Taxa abbreviation: Cyllo: Cylloepus, Gen: Genus undetermined; Heter: Heterelmis, Hexac: Hexacylloepus, Hexan: Hexanchorus, Macre: Macrelmis; Micro: Microcylloepus; Neoel: Neoelmis; Phano: Phanocerus; letter A at the end of genus name refers to adult stage; and F1, F2, F3 and C1, C2, C3 refer to the streams studied in forested (F) and converted (C) areas.

Microcylloepus Hinton, 1935 and Hexacylloepus Hinton, 1940, the larvae of Hexanchorus and Phanocerus, and adults of Macrelmis. However, they were associated with forested streams (F1 and F2). Both life stages of Heterelmis and adults of Cylloepus were positively associated with streams located in deforested areas, as well as stream width and land use.

The ISA showed significant indicator values of larval and adult stages of riffle beetles only in forested streams. Larvae of Macrelmis (IV $=100 \%$, $\mathrm{p}=0.004)$ and adults of Microcylloepus (IV $=94 \%$, $\mathrm{p}=0.029$ ) had the highest indicator values for forested streams. Larvae of Neoelmis and adults of Hexacylloepus, Macrelmis, and Neoelmis had marginally significant indicator values. Regarding substrate type, only larvae of Heterelmis showed a high indicator value for litter substrate, although it was marginally significant (IV $=73 \%, \mathrm{p}=0.071)$.

\section{DISCUSSION}

RESPONSES OF RIFFLE BEETLE ASSEMBLAGES TO DEFORESTATION AND THE VALUE OF SOME GENERA AS ENVIRONMENTAL INDICATORS OF FOREST INTEGRITY

Our results showed that assemblages of riffle beetles were sensitive to deforestation in the study area. Streams running through forested areas had assemblages with higher similarity and higher abundance of riffle beetles than those running through deforested and converted areas. Streams running through forested areas tend to be well shadowed with lower water temperature and higher dissolved oxygen values than those running through deforested areas. However, water abiotic descriptors had very similar values in forested and deforested streams in the study area. The presence of riparian vegetation in all streams (forested and deforested) should have prevented expressive 
TABLE II

Composition, richness and abundance of riffle beetle genera sampled in forested $(\mathrm{F})$ and deforested $(\mathrm{C})$ streams and

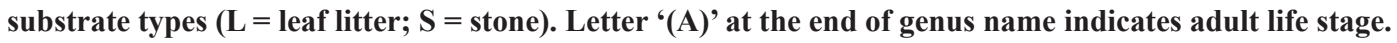

\begin{tabular}{|c|c|c|c|c|c|}
\hline \multirow[t]{2}{*}{ Genera } & \multicolumn{2}{|c|}{ Streams } & \multicolumn{2}{|c|}{ Substrate type } & \multirow[b]{2}{*}{ Total } \\
\hline & $\mathbf{F}$ & $\mathbf{C}$ & $\mathbf{L}$ & $\mathbf{S}$ & \\
\hline Cylloepus(A) & 0 & 1 & 1 & 0 & 1 \\
\hline Heterelmis & 302 & 277 & 421 & 158 & 579 \\
\hline Heterelmis(A) & 99 & 134 & 166 & 67 & 233 \\
\hline Hexacylloepus & 2 & 1 & 0 & 3 & 3 \\
\hline Hexacylloepus(A) & 18 & 10 & 9 & 19 & 28 \\
\hline Hexanchorus & 2 & 0 & 1 & 1 & 2 \\
\hline Macrelmis & 79 & 0 & 14 & 65 & 79 \\
\hline Macrelmis(A) & 22 & 2 & 5 & 19 & 24 \\
\hline Microcylloepus & 10 & 2 & 12 & 0 & 12 \\
\hline Microcylloepus(A) & 191 & 13 & 153 & 51 & 204 \\
\hline Neoelmis & 101 & 38 & 104 & 35 & 139 \\
\hline Neoelmis(A) & 13 & 2 & 3 & 12 & 15 \\
\hline Phanocerus(A) & 56 & 24 & 66 & 14 & 80 \\
\hline Gen Indet. A & 0 & 1 & 1 & 0 & 1 \\
\hline Abundance & 895 & 505 & 956 & 444 & 1.400 \\
\hline Richness & 7 & 9 & 8 & 7 & 9 \\
\hline
\end{tabular}

TABLE III

Eigenvalues, taxa-environment correlation coefficients, and cumulative percentage explained by the first four RDA axes of riffle beetle assemblages of streams in Parque Estadual do Turvo.

\begin{tabular}{|c|c|c|c|c|c|}
\hline Axes & Axis 1 & Axis 2 & Axis 3 & Axis 4 & Total variance \\
\hline Eigenvalues & 0.454 & 0.217 & 0.084 & 0.190 & 1.000 \\
\hline Species-environment correlations & 0.979 & 0.987 & 0.971 & 0.000 & \\
\hline \multicolumn{6}{|l|}{ Cumulative percentage variance } \\
\hline of taxa data & 45.4 & 67.1 & 75.4 & 94.4 & \\
\hline of taxa-environment relation & 60.2 & 88.9 & 100.0 & 0.0 & \\
\hline Sum of all eigenvalues & & & & & 1.000 \\
\hline Sum of all canonical eigenvalues & & & & & 0.754 \\
\hline
\end{tabular}

changes in water quality. The buffer effect provided by riparian vegetation, even when it is narrow and short in length (Lorion and Kennedy 2009), should also have prevented expressive increases in water temperature. Thus, the explanation for the differences found between assemblages from forested and deforested streams in the PET region should be related to other environmental descriptors.
Higher abundance of riffle beetles occurred in forested streams. The size of the forested area, the vegetation type (semi-deciduous forest) and the preservation condition should have enabled the differences found in the PET region. Previous studies have demonstrated the influence of largesized forest fragments, including wider riparian vegetation on macroinvertebrate assemblage 
structure (Couceiro et al. 2007, Iñiguez-Armijos et al. 2014, Moraes et al. 2014). This relationship has not been discussed so far, but it can be easily explained by the plasticity in the feeding habits of riffle beetles. Riffle beetles are shredders and grazers. Some genera feed on allochthonous vegetal matter, while others are xylophagous (Anderson and Sedell 1979, Elliott 2008). In fact, riffle beetles have been mainly considered shredders (Elliott 2008), and the abundance of this functional group is typically linked to the abundance of litter (Cummins et al. 1989), which has higher input in streams flanked by deciduous vegetation (Frady et al. 2007). Thus, the greater the size of the forest and the wider the riparian vegetation, the higher the abundance of shredders (Weigel 2003, Frady et al. 2007, Lorion and Kennedy 2009, Valle et al. 2010, Iñiguez-Armijos et al. 2014).

Riffle beetle assemblages were more similar within the PET area than in the nearby deforested areas. Previous studies have also recorded more similar macroinvertebrate assemblages in streams from forested areas than deforested ones (Death and Collier 2010, Corbi et al. 2013, Iñiguez-Armijos et al. 2014, Bertaso et al. 2015). Disturbances promoted by agricultural activities as well as environmental heterogeneity (Heino 2000) are important drivers of freshwater macroinvertebrate diversity. Thus, the occurrence of more dissimilar riffle beetle assemblages among deforested streams should have been determined by the greater variation in landscape-scale environmental descriptors, particularly the occurrence of different exotic species in the riparian vegetation (e.g., Eucalyptus and Japanese raisin). Previous studies have shown that exotic vegetation remains entering streams affect macroinvertebrate assemblages because their leaves have lower nutritional quality and reduced palatability (Graça et al. 2002, 2015, Márquez et al. 2015). Thus, exotic vegetation also affects shredder organisms (Death and Collier
2010), including riffle beetles (Huamantinco and Nessimian 1999).

Many riffle beetle genera and life stages showed high value as indicators of forest integrity in the PET region. Previous studies analyzing the influence of forest removal and conversion to agricultural uses on stream macroinvertebrate assemblages have recorded the occurrence of riffle beetles, especially (or exclusively) in streams running into native forest and grassland areas (Paula and FonsecaGessner 2010, Azevedo et al. 2012, Corbi et al. 2013, Iñiguez-Armijos et al. 2014). In this study, Neoelmis, Hexacylloepus and Microcylloepus were indicative of forested streams. These genera have been found in streams located in forested areas from other regions (Lorion and Kennedy 2009, Paula and Fonseca-Gessner 2010, Corbi et al. 2013, IñiguezArmijos et al. 2014). Cylloepus and Phanocerus showed weak relationships with deforested streams in the PET region and were previously associated with streams running into forested areas (Paula and Fonseca-Gessner 2010, Corbi et al. 2013, Iñiguez-Armijos et al. 2014). Heterelmis has been recorded in streams located in both impacted and protected areas (Paula and Fonseca-Gessner 2010). The larval stage of Macrelmis showed the highest indicative value for PET forested area, suggesting a relation to the presence of native vegetation leaves with good nutritional quality. The adult stage of Microcylloepus, which had the second highest indicative value for forested areas, was previously associated with preserved areas (Paula and Fonseca-Gessner 2010). In other words, except for the adult and larval stages of Heterelmis, many other genera and their life stages seem to be strongly associated with forested areas and constitute good environmental indicators of forest integrity.

Factors related to forest environmental integrity, such as land use, stream width, and distance from the forest edge, were important drivers of riffle beetle assemblage structure in the PET region. However, the influence of the distance 
from the forest edge is possibly related to the effects of isolation and dispersal ability of riffle beetles. Connectivity is a strong driver of stream insect assemblages, mostly due to dispersal limitation (Rosenberg and Resh 1993). Riffle beetles disperse via drift and flight (Elliott 2008), although their dispersal ability is limited because adults seldom leave the water after settling (Yee and Kehl 2010). In this study, sites that were more distant from each other had different compositions. Therefore, spatial isolation must have played an important role in structuring riffle beetle assemblages in the PET region.

\section{SUBSTRATE INFLUENCE ON RIFFLE BEETLE ASSEMBLAGES}

Riffle beetle assemblages in leaf litter substrate had higher abundance than in stone substrate. Previous studies also recorded riffle beetle assemblages with higher richness and abundance in leafy substrates than in other substrate types (Tavares and Williams 1990, Passos et al. 2003a, b, Azevedo et al. 2012, Graça et al. 2015). This relationship was attributed to the importance of vegetal remains to the life habits of riffle beetles. In contrast, richness was very similar between assemblages inhabiting both substrate types in the study area. Some previous studies also found rich and very abundant assemblages in stony streambeds, where litter does not accumulate (Brown 1987, Elliott 2008, Braun et al. 2014a). This result may be determined by the scraper feeding habit of riffle beetles over rocks (Elliot 2008), which leads to the occurrence of similar richness between both substrate types in the PET region.

Heterelmis was indicator of substrate type, although showing marginally significant value. Larvae of Heterelmis, which were associated with litter substrate, have been classified as generalist collectors (including the adult stage) in Neotropical streams (Chara-Serna et al. 2012). However, they have also been found in predominantly stony substrates (Braun et al. 2014a) and in very impacted areas (Corbi et al. 2013). Thus, species of Heterelmis should also be tolerant to differences in substrate type, as suggested by the marginal significance of its indicative value in the PET region.

\section{CONCLUSIONS}

The structure of riffle beetle assemblages was sensitive to forest integrity in the PET conservation unit and to land use in nearby agricultural converted areas. Riffle beetle assemblages had lower abundance and similarity in deforested streams. In addition, some genera such as Macrelmis and Microcylloepus showed indicator value of environmental integrity in streams from semideciduous Atlantic Forest remnants. Furthermore, the assemblages had higher abundance in litter than in stone substrate, reinforcing the role of substrate type in the structure of their assemblages. Our results could be related to specific features of the study area, such as the importance of the amount and quality of the allochthonous organic matter entering the streams, since the input of a broad array of vegetal remains (leaves, branches, twigs, and woody debris) is guaranteed in native forested streams (Marquéz et al. 2015). In contrast, streams running in converted areas contained exotic vegetation, which likely affected the establishment of shredder organisms such as riffle beetles. In summary, we suggest that the quality of the riparian vegetation (native) be as important as its buffer role in structuring riffle beetle assemblage structure.

Finally, we recommend that the role of temporal changes in the input of native allochthonous matter in structuring riffle beetle assemblages be further investigated. The input of organic matter from native deciduous to semi-deciduous vegetation is not seasonal in Neotropical streams (Gonçalves et al. 2006). Complementarily, many streams from temperate areas in the Holarctic Region also have riparian vegetation with seasonal (deciduous 
vegetation) input patterns, and show lower vegetation diversity than in subtropical areas of the Neotropical Region (Campbell et al. 1992). Thus, through similar mechanisms, the role of riparian vegetation in influencing riffle beetle assemblages can differ between the different vegetation types in the Atlantic Forest biome (e.g., subtropical semideciduous type covered in this study and tropical evergreen ones) and zoogeographical regions.

\section{ACKNOWLEDGMENTS}

We thank biologists Marlon da Luz Soares and Viviane Souza Mirada for their inestimable help in the data collection in field. Thanks to Secretaria do Ambiente e Desenvolvimento Sustentável (SEMA-RS), for permission to conduct research in the Parque Estadual do Turvo, and Instituto Chico Mendes de Conservação da Biodiversidade (ICMBIO), for the collecting license (26085-1). Coordenação de Aperfeiçoamento de Pessoal de Nível Superior (CAPES) is thanked for granting a scholarship to the first author, T.R.N. Bertaso, and to M.M. Pires.

\section{REFERENCES}

ANDERSON NH AND SEDELL JR. 1979. Detritus processing by macroinvertebrates in stream ecosystems. Annu Ver Entomol 24: 351-377.

AZEVEDO RS, DUMAS L, RODRIGUES D, REZENDE CR, CARAMASCHI EP, MAZZONI R AND NESSIMIAN J. 2012. Community of Aquatic Macroinvertebrates in an Atlantic Forest Stream, Brazil. EntomoBrasilis 5: 179-184.

BARBOSA FF, FERNANDES AS AND OLIVEIRA LG. 2013. Taxonomic key for the genera of Elmidae (Coleoptera, Byrrhoidea) occurring in Goiás state, Brazil, including new records and distributional notes. Rev Bras Entomol 57: 149-156.

BERTASO TRN, SPIES MR, KOTZIAN CB AND FLORES MLT. 2015. Effects of forest conversion on the assemblages' structure of aquatic insects in subtropical regions. Rev Bras Entomol 59: 43-49.

BRAUN BM, PIRES MM, KOTZIAN CB AND SPIES MR. 2014b. Diversity and ecological aspects of aquatic insect communities from montane streams in southern Brazil. Acta Limnol Bras 26: 186-198.
BRAUN BM, PIRES MM, STENERT C, MALTICHIK AND KOTZIAN CB. 2018. Effects of riparian vegetation width and substrate type on riffle beetle community structure. Entomol Sci 21: 66-75.

BRAUN BM, SALVARREY AVB, KOTZIAN CB, SPIES MR AND PIRES MM. 2014a. Diversity and distribution of riffle beetle assemblages (Coleoptera, Elmidae) in montane rivers of Southern Brazil. Biota Neotrop 14: 1-11.

BROWN HP. 1972. Aquatic Dryopoid beetles (Coleoptera) of United States. Biota of freshwater ecosystem, identification manual no. 6 - Aquatic Dryopoid Beetles (Coleoptera) of the United States Environmental Protection Agency, Ohio, $82 \mathrm{p}$.

BROWN HP. 1987. Biology of Riffle Beetles. Annu Rev Entomol 32: 253-273.

CAMPBELL IC, JAMES KR, HART BT AND DEVEREAUX A. 1992. Allochthonous coarse organic material in forest and pasture reaches of two south-eastern Australian streams. II. Litter processing. Freshw Biol 27: 353-365.

CHARA-SERNA AM, CHARA JD, ZUNIGA MD, PEARSON RG AND BOYERO L. 2012. Diets of leaf litter-associated invertebrates in three tropical streams. Ann Limnol 48: 139-144.

CORBI JJ, KLEINE P AND TRIVINHO-STRIXINO S. 2013. Are aquatic insect species sensitive to banana plant cultivation? Ecol Indic 25: 156-161.

COUCEIRO SRM, HAMADA N, LUZ SLB, FORSBERG B AND PIMENTEL TP. 2007. Deforestation and sewage effects on aquatic macroinvertebrates in urban streams in Manaus, Amazonas, Brazil. Hydrobiologia 575: 271-284.

CUMMINS KW, WILZBACH MA, GATES DM, PERRY JB AND TALIAFERRO WB. 1989. Shredders and riparian vegetation. BioScience 39: 24-30.

DEATH RG AND COLLIER KJ. 2010. Measuring stream macroinvertebrate responses to gradients of vegetation cover: when is enough enough? Freshw Biol 55: 14471464.

DOMÍNGUEZ E AND FERNÁNDEZ HR. 2009. Macroinvertebrados Bentônicos Sudamericanos. Sistematica y Biologia. Fundacion Miguel Lillo, San Miguel de Tucumán, 282 p.

DUFRÊNE M AND LEGENDRE P. 1997. Species assemblages and indicator species: the need for a flexible asymmetrical approach. Ecol Monograph 67: 345-366.

ELLIOTT JM. 2008. The ecology of riffle beetles (Coleoptera: Elmidae). Freshw Rev 1: 189-203.

FEND SV AND CARTER JL. 2005. Relationships of Field Habitat Measurements, Visual Habitat Indices, and Land Cover to Benthic Macroinvertebrates in Urbanized Streams of the Santa Clara Valley, California. Am Fish Soc Symp 47: 193-212.

FRADY C, JOHNSON S AND LI J. 2007. Stream macroinvertebrate community responses as legacies of 
forest harvest at the H.J. Andrews Experimental Forest, Oregon. Forest Sci 53: 281-293.

GONÇALVES JF, FRANÇA JS AND CALLISTO M. 2006. Dynamics of allochthonous organic matter in a tropical Brazilian headstream. Braz Arch Biol Technol 49: 967973.

GRAÇA MAS, FERREIRA WR, FIRMIANO K, FRANÇA J AND CALLISTO M. 2015. Macroinvertebrate identity, not diversity, differed across patches differing in substrate particle size and leaf litter packs in low order, tropical Atlantic Forest streams. Limnetica 34: 29-40.

GRAÇA MAS, POZO J, CANHOTO C AND ELOSEGI A. 2002. Effects of Eucalyptus plantations on detritus, decomposers, and detritivores in streams. Scientific World J 2: 1173-1185.

HEINO J. 2000. Lentic macroinvertebrate assemblage structure along gradients in spatial heterogeneity, habitat size and chemistry. Hydrobiologia 418: 229-242.

HUAMANTINCO AA AND NESSIMIAN JL. 1999. Estrutura e distribuição espacial da comunidade de larvas de Trichoptera (Insecta) em um tributário de primeira ordem do Rio Paquequer, Teresópolis, RJ. Acta Limnol Bras 11: 1-16.

IÑIGUEZ-ARMIJOS C, LEIVA A, FREDE HG, HAMPEL H AND BREUER L. 2014. Deforestation and benthic indicators: how much vegetation cover is needed to sustain healthy Andean streams? PLoS ONE 9: 1-10.

LORION CM AND KENNEDY BP. 2009. Riparian forest buffers mitigate the effects of deforestation on fish assemblage in tropical headwater streams. Freshw Biol 19: 468-479.

MALUF JMT. 2000. Nova classificação climática do Estado do Rio Grande do Sul. Rev Bras Meteorol 8: 141-150.

MANZO V. 2005. Key to the South America genera of Elmidae (Insecta: Coleoptera) with distributional data. Stud Neotrop Fauna E 40: 201-208.

MÁRQUEZ JA, CIBILS L, PRINCIPE RE AND ALBARIÑO RJ. 2015. Stream macroinvertebrate communities change with grassland afforestation in central Argentina. Limnologica 53: 17-25.

MARTÍNEZ PA, FREDES NA, MONTII LF AND CASERTANO SA. 2009. Soil oribatid mite in four typical vegetation communities of Misiones Forest in the Iguazú area, Argentina. Pesq Agropec Bras 44: 1021-1026.

MORAES AB, WILHELM AE, BOELTER T, STENERT C, SCHULZ UH AND MALTCHIK L. 2014. Reduced riparian zone width compromises aquatic macroinvertebrate communities in streams of southern Brazil. Environ Monit Assess 186: 7063-7074.

NESSIMIAN JL, VENTICINQUE EM, ZUANON J, DE MARCO P, GORDO M, FIDELIS L, BATISTA J AND JUEN L. 2008. Land use, habitat integrity, and aquatic insect assemblages in Central Amazonian streams. Hydrobiologia 614: 117-131.

OLIVEIRA-FILHO AT, BUDKE JC, JARENKOW JA, EISENLOHR PV AND NEVES DRM. 2015. Delving into the variations in tree species composition and richness across South American subtropical Atlantic and Pampean forests. J Plant Ecol 6: 1-23.

PASSOS MIS, NESSIMIAN JL AND DORVILLÉ LFM. 2003a. Distribuição espaço-temporal da comunidade de Elmidae (Coleoptera) em um rio na Floresta da Tijuca, Rio de Janeiro, RJ. Bol Museu Nac 509: 1-9.

PASSOS MIS, NESSIMIAN JL AND DORVILLÉ LFM. 2003b. Life strategies in an Elmidae (Insecta: Coleoptera: Elmidae) community from a first order stream in the Atlantic Forest, southeastern Brazil. Acta Limnol Bras 15: 29-36.

PASSOS MIS, NESSIMIAN JL AND FERREIRA JRN. 2007. Chaves para identificação dos gêneros de Elmidae (Coleoptera) ocorrentes no Estado do Rio de Janeiro, Brasil. Rev Bras Entomol 51: 42-53.

PAULA MC AND FONSECA-GESSNER AA. 2010. Macroinvertebrates in low-order streams in two fragments of Atlantic Forest in different states of conservation, in the State of São Paulo (Brazil). Braz J Biol 70: 899-909.

QUINN JM, BOOTHROYD IKG AND SMITH BJ. 2004. Riparian buffers mitigate effects of pine plantation logging on New Zealand streams 2. Invertebrate communities. Forest Ecol Manag 191: 129-146.

REID DJ, QUINN JM AND WRIGHT-STOW AE. 2010. Responses of stream macroinvertebrate communities to progressive forest harvesting: Influences of harvest intensity, stream size and riparian buffers. Forest Ecol Manag 260: 1804-1815.

ROSENBERG DM AND RESH VH. 1993. Freshwater Biomonitoring and Benthic Macroinvertebrates. New York: Chapman \& Hall, 488 p.

ROY AH, ROSEMOND AD, PAUL MJ, LEIGHT DS AND WALLACE JB. 2003. Stream macroinvertebrate response to catchment urbanisation (Georgia, U.S.A.). Freshw Biol 48: 329-346.

SALVARREY AVB, KOTZIAN CBK, SPIES MR AND BRAUN BM. 2014. The influence of natural and anthropic environmental variables on the structure and spatial distribution along longitudinal gradient of macroinvertebrate communities in southern Brazilian streams. J Insect Sci 14(13): 1-23.

SEAGLE JR HH. 1982. Comparison of the food habitats of three species of riffle beetles, Stenelmis crenata, Stenelmis mera, and Optioservus trivittatus (Coleoptera, Dryopoidea, Elmidae). Freshw Invert Biol 1: 33-38.

SEGURA MO, VALENTE-NETO F AND FONSECAGESSNER AA. 2012. Checklist of the Elmidae (Coleoptera: Byrrhoidea) of Brazil. Zootaxa 3260: 1-25. 
SEMA. 2005. Plano de Manejo do Parque Estadual do Turvo. Secretaria Estadual do Meio Ambiente.

SHEARER KA AND YOUNG RG. 2011. Influences of geology and land use on macroinvertebrate communities across the Motueka River catchment, New Zealand. New Zeal J Mar Fresh 45: 437-454.

TAVARES AF AND WILLIAMS DD. 1990. Life histories, diet, and niche overlap of three sympatric species of Elmidae (Coleoptera) in a temperate stream. Can Entomol 122: 563-577.

TER BRAAK CJF AND ŠMILAUER P 2002. CANOCO Reference manual and CanoDraw for Windows User's guide: Software for Canonical Community Ordination (version 4.5). Microcomputer Power.

TOMANOVA S, GOITIA E AND HELESIC J. 2006. Trophic levels and functional feeding groups of macroinvertebrates in Neotropical streams. Hydrobiologia 556: 251-264.
VALLE IC, BUSS DF AND BAPTISTA DF. 2010. The influence of connectivity in forest patches, and riparian vegetation width on stream macroinvertebrate fauna. Braz J Biol 73: 231-238.

WEIGEL BM, WANG L, RASMUSSEN PW, BUTCHER JT, STEWART PM, SIMON, TP AND WILEY MJ. 2003. Relative influence of variables at multiple spatial scales on stream macroinvertebrates in the Northern Lakes and Forest ecoregion, U.S.A. Freshw Biol 48: 1440-1461.

WHITE DS AND BRIGHAM WU. 1996. Aquatic Coleoptera. In: Merritt RW and Cummins KW (Eds), Introduction to the Aquatic Insects of North America, $3^{\text {rd }}$ edition, Kendall/ Hunt Publ. Co., Iowa, p. 399-473.

YEE DA AND KEHL S. 2010. Order Coleoptera. In: Thorp JH and Covich AP (Eds), Ecology and classification of North American freshwater invertebrates. San Diego, Academic Press, Inc., 911 p. 